RASĀYAN J. Chem.

Vol. 13 | No. 3 |1580-1588| July - September | 2020 ISSN: 0974-1496 | e-ISSN: 0976-0083 | CODEN: RJCABP

RJC http://www.rasayanjournal.com http://www.rasayanjournal.co.in

\title{
REVIEW ON ISOLATION, IDENTIFICATION AND APPLICATIONS OF Simarouba glauca PLANT
}

\author{
D. Siva Selvi ${ }^{1}$, N. Vijayakumar ${ }^{1, *}$, R. Jayaprakash ${ }^{2}$ and M. Reddi Nagesh ${ }^{1}$ \\ ${ }^{1}$ Department of Biochemistry and Biotechnology, Annamalai University, \\ Annamalainagar-608002, Tamil Nadu, India \\ ${ }^{2}$ Department of Chemistry, School of Arts and Science, AVIT Campus, VMRF, \\ Chennai-603104, Tamil Nadu, India. \\ *E-mail: nvkbiochem@yahoo.co.in
}

\begin{abstract}
Natural Plant species and traditional methods are valuable in the medical field to control various diseases. Recently natural plant-based medicines have received major attention in the medical research field and act as a vital part of healthcare. Also, these natural bioactive compounds are the basic molecules for the new drug synthesis. But the researchers are facing problems such as species identification, isolation of active compounds and their medicinal action in different therapeutic fields in research. This work investigated the completed research and its outcomes of the identification of new biologically active plants and their active parts. Based on the social problem, this review also investigated the Simarouba Glauca plant extraction, isolation of active compounds from the plant and phytochemical analysis of the reported research outcomes. Because, global health challenging illnesses like cancer, diabetes and AIDS are increasing due to the lacking of synthetic medicines. So the new researchers are concentrating on natural plants, algae and sea living organisms for drug development. Hence this work concentrated to identify the usefulness of Simarouba Glauca plant and different work carried on the plant products. These kinds of plant extracts are tested for various biotechnology methods to evaluate its drug suitability.
\end{abstract}

Keywords: Simarouba Glauca, Medicinal Plants, Identification, Isolation, Applications.

(C) RASĀYAN. All rights reserved

\section{INTRODUCTION}

Nowadays plants are acting as an important role in the medical field. Traditional plants are used as medicines by the peoples still today. The main advantages of the natural plants are not showing any side effects between the peoples. These treatments are classified into different types based on the plant parts using methods such as Siddha, Rasashastra, Unani, Sa-Rigpa, Ayur vedha, yoga, and Chinese as per the Indigenous Medicines of India. ${ }^{1}$ World Health Organization (WHO) exposed that $80 \%$ of the world people are depending on the plant-based medicines because of low cost and availability to fulfill their primary healthcare needs. ${ }^{2}$ But due to the side effects of synthetic drugs, herbal drugs and their requirements are increasing day-by day. ${ }^{3}$ Developing countries people are using medicinal plants due to poverty and its availability in nearby areas. ${ }^{4}$ The habit of using medicinal plants has been increasing every year and most of the Americans are also started to use herbal products. ${ }^{5}$ So, natural drug usage is increasing to overcome the different ill effects. ${ }^{6}$ Hence this research reviewed the reports about the Simarouba Glauca (SBGA) tree parts and its usefulness in different therapeutic fields instead of selecting small herbs and small plants. ${ }^{7}$ Due to the availability of the trees than herbs or plants, this work selected the Shorgum Maram (Lakshmi Taru tree) which is growing in water-holding soil and sub-soil moisture. The commonly known Paradise or Bitter wood tree (Fig.-1) is in the order of Sapindales which is in the family of Simaroubaceae.

\section{Alternative Names of Simarouba Glauca}

The Simarouba Glauca can be called as bitter ash, Paradise tree, acajou blanc, daguillo gavilan, olivio, palo amargo, bwa fwenn, doliv fwenn, bois amer, quinquina, Mountain Damson, Simarouba, Dysentry bark and Acituno based on the available countries.

Rasayan J. Chem., 13(3), 1580-1588(2020)

http://dx.doi.org/10.31788/RJC.2020.1335793

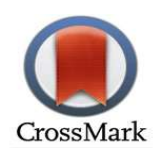


RASĀYAN J. Chem.

Vol. 13 | No. 3 |1580-1588| July - September | 2020
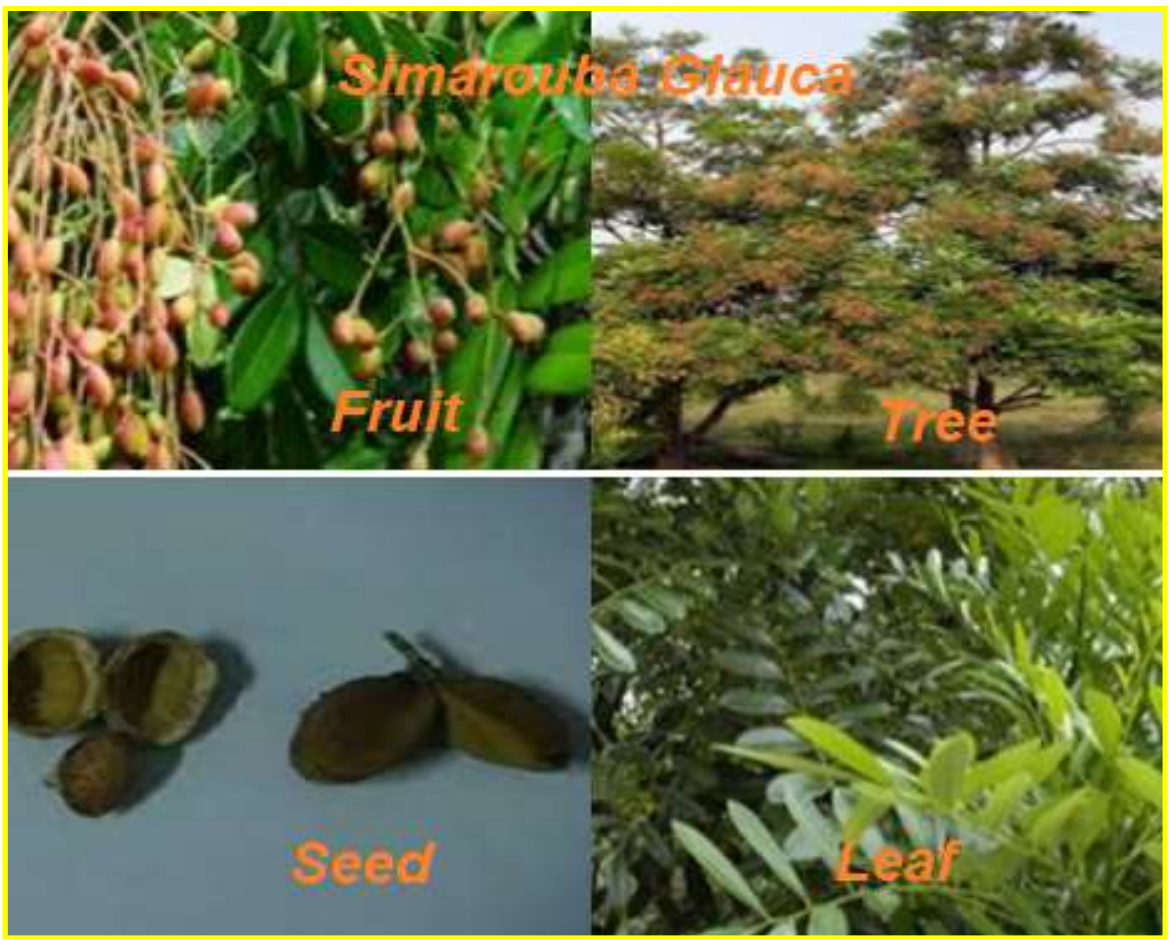

Fig.-1. Simarouba Glauca (SBGA) Plant Parts

\section{Global Distribution of Paradise Tree}

The paradise tree is globally available in the following countries such as Southern Florida, West Indies, Brazil ahamas, Costa Rica, Cuba, EI-Salvador, Guatemala, Haiti, Honduras, Jamaica, Mexico, Puertorico, united states of America, Srilanka, India, Phillippines and Myanmar. ${ }^{8}$

\section{Various Uses of Plant Parts}

The seeds of Simarouba glauca contain $60-75 \%$ oil. It can be easily processed which is suitable for both edible and non-edible applications. Each complete grown tree yields 15 to $30 \mathrm{~kg}$ nuts, which is equivalent to $2.5-5 \mathrm{~kg}$ oil. The oil is isolated from the Simarouba Glauca seeds. ${ }^{9}$

\section{Various Reports on SBGA}

\section{RESULTS AND DISCUSSION}

Recently SBGA extracts and its parts are used for various applications. Hence at first, this work referred to the recent reports. Based on the reports, this review extended up to 2000. Jose et al. has testified the hexane, ethyl acetate, 70\% ethanol-water, chloroform, leaf extracts of SBGA on HCT-116 and HCT-15 cells by well-known Sulforhodamine-B assay. ${ }^{10}$ The outcomes revealed that the chloroform extract exhibited maximum anticancer activity and they have isolated a potent molecule from the extract and shown in Fig.-2(a). The reported anticancer activity of chloroform extract has displayed in Fig.-2(b). Sridevi et al.have exposed the in vitro antioxidant and MTT assay on T-24 (Bladder cancer cell) cancer cell using methanol, chloroform, ethanol, hydro alcohol ethyl acetate and water extracts of the leaf. ${ }^{11}$ Using Folin-Ciocalteu reagent, the Phenolic content of the extracts was measured and reported. The same extracts were carried for 2,2-Diphenyl-1-picrylhy- drazyl (DPPH) radical scavenging assay, Ferric ion reducing antioxidant power (FRAP) assay, Phosphomolybdenum (PM) assay for their antioxidant property. Their result and conclusion stated that alcoholic extracts showed more antioxidant and cancer activity. K.S. Lakshmi et al. have reported the different solvent extraction of the leaves using chloroform, methanol and ethyl acetate solvents. ${ }^{12}$ Further, these extracts were carried for the phytochemical analysis followed by an antioxidant, antimicrobial, thrombolytic and hemolytic activities. Their Phytochemical analysis confirmed the main chemical constituents such as alkaloids, a phenolic compound, terpenoids, flavonoids, glycosides, and cardinolides. The outcomes exposed that the increase in concentration 
RASĀYAN J. Chem.

Vol. 13 | No. 3 |1580-1588| July - September | 2020

exposed to increasing activity. The extract exhibited scavenging activity $\mathrm{IC}_{50}=6.72 \mu \mathrm{g} / \mathrm{mL}$ for chloroform extract. Rajurkar B.M et al. have described the leaves of Clerodendrum infortunatum Linn, Simarouba glauca and Psoraleacory lifolia ethanolic extracts and their antimicrobial activity. ${ }^{13}$ The research outcomes showed the good inhibitory activity of the extracts when compared to tetracycline standard drugs. Patil et al. have reviewed the various uses of Simarouba Glauca. ${ }^{14}$ This review also exposed the bark of SBGA used for dysentery control. Also, this review exposed the medicinal properties of bark, leaf extracts pharmacological activities such as antiparasitic, antipyretic, anticancerous and antidysentric.

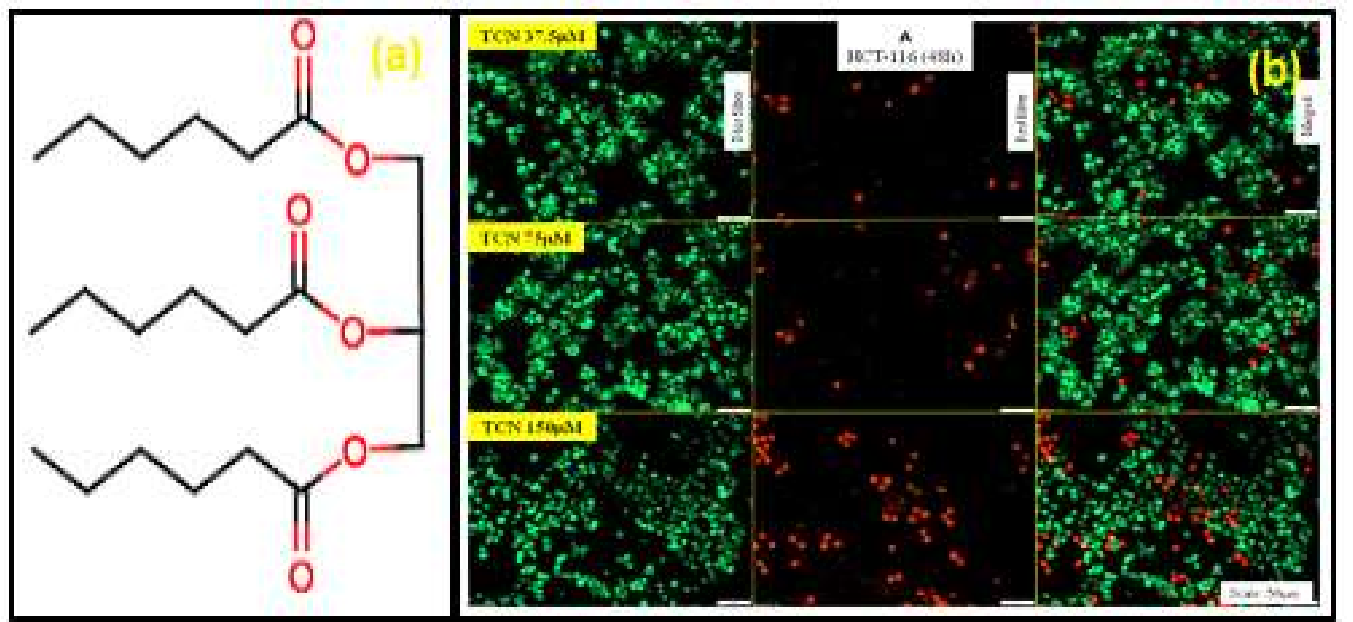

Fig.-2: (a)Tricaproin from Chloroform Extract, (b)Anticancer Activity of the SBGA Chloroform Extract ${ }^{10}$

In addition to this they have summarized the pharmacological, Phytochemical and Ethnobotanical characters of the SBGA. Some of the chemicals isolated from the seed also reported in the review, which is displayed in Fig.-3. Padovan et al. have reported the effect of the root of the Tabebuia rosea Bertol and evergreen Simarouba Glauca when they planted in a selected soil. ${ }^{15}$ In addition to this, the report also correlated the root effect with the rainfall. The research conclusion exposed that the Simarouba Glauca roots effect on coffee roots and enhance the soil nutrients.

The vegetable oils are the source for biodiesel research nowadays as per the reports. ${ }^{16}$ They have examined the Jatropha, Pongamia and Simarouba oils for biodiesel research. The outcomes exhibited the biodiesel property of the seed oil. The seed and oil quantity relation graph showed in Fig.-4. The conclusion confirmed that the Simarouba Glauca is the best source for the biodiesel preparation. The same kind of work already carried and reported by Chavan et al. ${ }^{17}$ Their outcomes also supported the biodiesel property of SBGA.

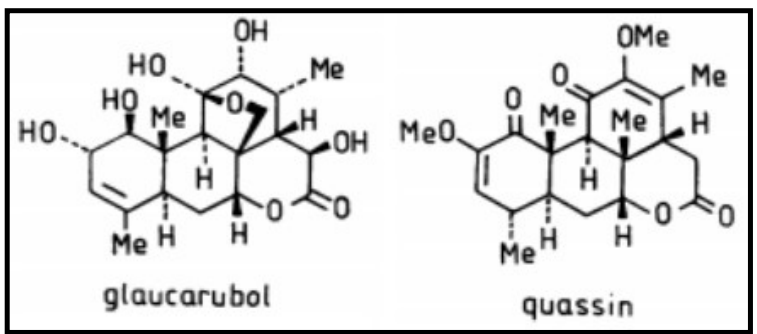

Fig.-3: Isolated Compounds from SBGA ${ }^{15}$

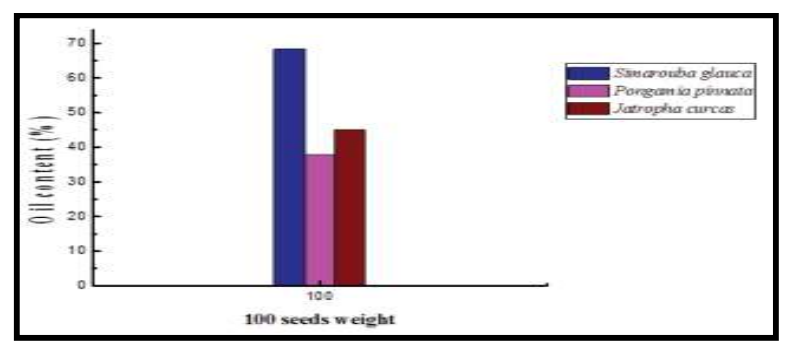

Fig.-4: Graphical Representation of weight of Seeds Vs. Oil Content ${ }^{16}$

\section{Phytochemical Analysis}

Sharanya et al. have reported the SBGA various parts of the plants for diseases like amoebiasis, malaria, ulcer, antibacterial, cancer, antifungal, snake bite, etc. this pharmacological review revealed the Simarouba glauca medicinal potential. ${ }^{18}$ Assendelft et al. have isolated the crystalline glycoside for the 
RASĀYAN J. Chem.

Vol. 13 | No. 3 |1580-1588| July - September | 2020

treatment of amoebiasis. ${ }^{19}$ Similarly Kartha et al. has reported the structure of characterized crystal structure. ${ }^{20}$ Both works have completed the glycoside structure which is displayed in Fig.-5. SBGA plants exhibited both antimalarial and anticancer activity. ${ }^{21}$ Twelve compounds were isolated from the chloroform extract of southern Florida SBGA twig. ${ }^{22}$ They were tested against the epidermoid tumor cell line. Out of twelve, 14-Deacetyleurylene (Fig.-6) was active against the Lu1 cancer cell line and inactive for in-vivo hollow fiber assay.

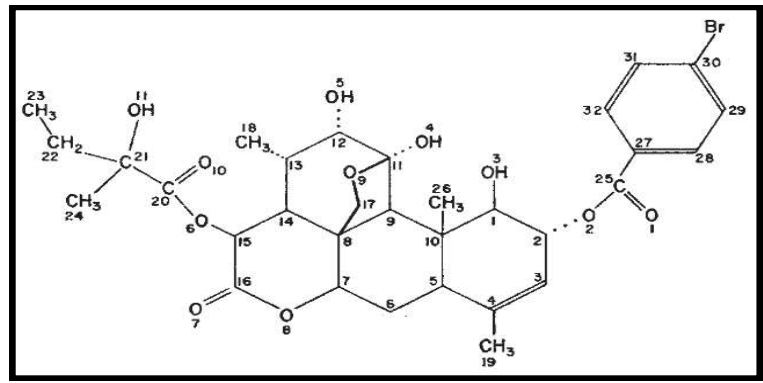

Fig.-5: Glycoside Structure from SBGA ${ }^{20}$

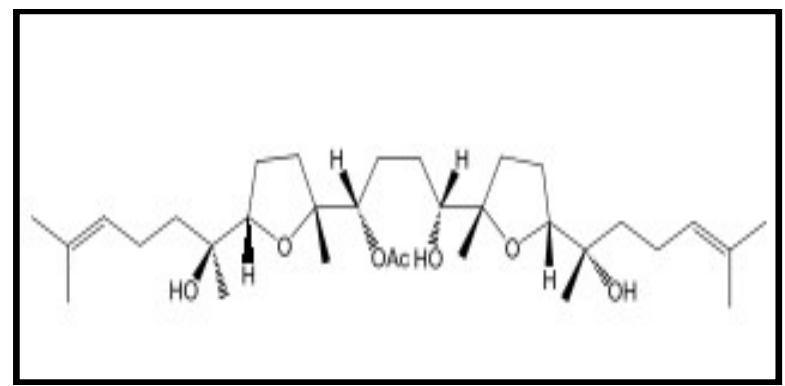

Fig.-6: Structure of 14- Deacetyleurylene ${ }^{22}$

Two toxic quassinoid glucosides were isolated from aqueous extract Simarouba glauca seeds for new biological compounds preparation. Their structures were deduced by spectral and single-crystal (Fig.-7) X-ray analysis. ${ }^{23}$ SBGA plant can be effectively identified by Random Amplified Polymorphic DNA (RAPD) to eliminate the non-profitable male seedlings. ${ }^{24}$ SBGA various parts (bark, flowers and leaves) were extracted using ethanol, chloroform, methanol, and water solvents for their antioxidant property. Different antioxidant assays were carried and the results revealed that the aqueous extract of the bark is an effective antioxidant when compared to other parts. ${ }^{25}$ Different varieties of 32 genera and 170 species, including Simaroubaceae and their chemical constituents were reviewed and the research gaps regarding patents were initiated. ${ }^{26}$ Some of the triterpenes have presented in Fig.-8.

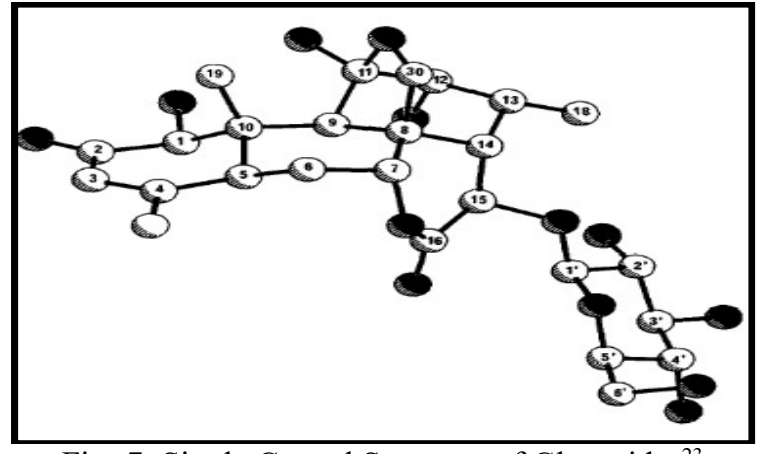

Fig.-7: Single Crystal Structure of Glucosides ${ }^{23}$

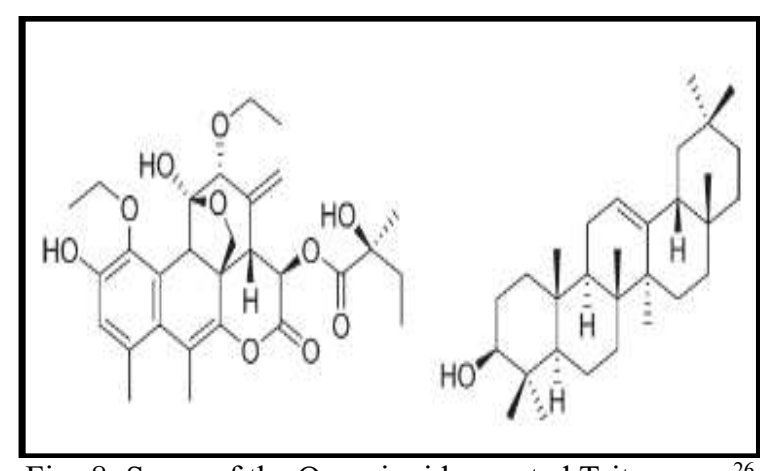

Fig.-8: Some of the Quassinoid reported Triterpenes ${ }^{26}$

\section{Antimicrobial and Anticancer Activity}

In addition to these the SBGA parts and their biological activities were reviewed between 1953 and 2014 merely 105 journals. ${ }^{27}$ The isolated greenish-yellow, odorless fat exhibited properties such as melting point $-26.4{ }^{\circ} \mathrm{C}$, Iodine value -52.6 , saponification value -190.5 and oil content of $60-100 \mathrm{~g}$. Latter on the review stated that the aqueous extract showed the equal contents of cinnamon bark. The SBGA crude extract was tested against cancer cell lines KG-1, K-562 and MOLT-3 using different concentrations leaf extract by MTT assay. ${ }^{28}$ The polar methanolic solvent extract SBGA leaves exposed noticeable anticancer activity against MOLT-3 $\left(\mathrm{IC}_{50}-69.69 \mu \mathrm{g} / \mathrm{ml}\right)$ and $\mathrm{K}-562\left(\mathrm{IC}_{50}-74.21 \mu \mathrm{g} / \mathrm{ml}\right)$ when compared to $\mathrm{KG}-1$ $\left(\mathrm{IC}_{50}-131.1 \mu \mathrm{g} / \mathrm{ml}\right)$ cell lines. The SBGA plant parts can be used for leukemic cancers. Three active quassinoids of Simarouba Glauca were inhibited against chloroquine-resistant Plasmodium falciparum strain by both in-vitro and in-vivo studies. ${ }^{29}$ Plants of SBGA are used as drugs mainly to cure cancer which contains the anthraquinones, phenylpropanoids, Polyphenols, flavonoids, coumarins, limonoids, 
RASĀYAN J. Chem.

Vol. 13 | No. 3 |1580-1588| July - September | 2020

lignans, quinines, vitamins and fatty acids which were identified by phytochemical analysis. ${ }^{30}$ SBGA pharmacological study against entophytic fungus Penicillium pimiteouiense was reported and the activity (Fig.-9) is due to the presence of the above reported different organic compounds (Fig.-10) by phytochemical analysis. ${ }^{31}$

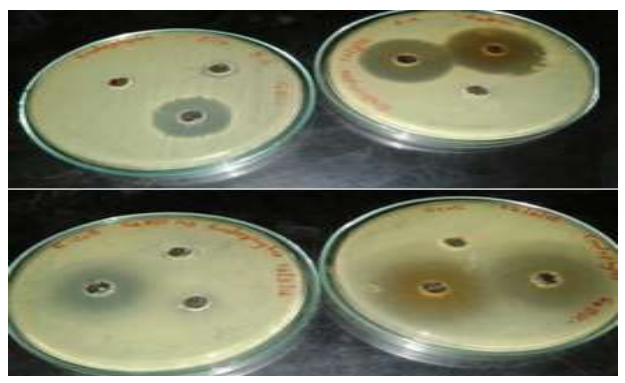

Fig.-9: Antimicrobial Activity of SBGA against the Fungal Extract Bacteria ${ }^{31}$

\begin{tabular}{|c|c|c|c|}
\hline Phytoehenilal & Test & Result & Inference \\
\hline Flavanoids & Shinoda's lest & Reddish brown colour & Positive \\
\hline Phenols & $\mathrm{FeCl}_{j}$ lest & No dark grecnblue colour & Negative \\
\hline Alkaloids & Mayer's lest & Pale creany precipiatate & Postive \\
\hline Cardiac glyoosides & Keller -Kiliani lest & No greenish blue colour & Negative \\
\hline Triteppenoids & Sallkowski's test & Reddish brown colour & Poitive \\
\hline Cantobydates & Molihh's test & Raddish violet ring & Posilive \\
\hline Saponins & Frolbing lest & No stable froth & Negative \\
\hline Tannin & $\mathrm{FeCl}$ lest & No blue green or blue black colour & Negative \\
\hline
\end{tabular}

Fig.-10: Phytochemical Analysis of SBGA ${ }^{31}$

An anticancer ability of quassinoids compounds of SBGA was carried by docking against PI3K (Phosphoinositide 3- kinases. Fig.-11) and adme analysis. The resulting outcomes showed the binding ability and supported anticancer activity. ${ }^{32}$ Nanoparticles that can be prepared by using plant extracts were investigated using silver nitrate and silver nanoparticles (AgNPs) formed with leaf extract SBGA. ${ }^{33,34}$ It can act as a very good antimicrobial agent as shown in Fig.-12.

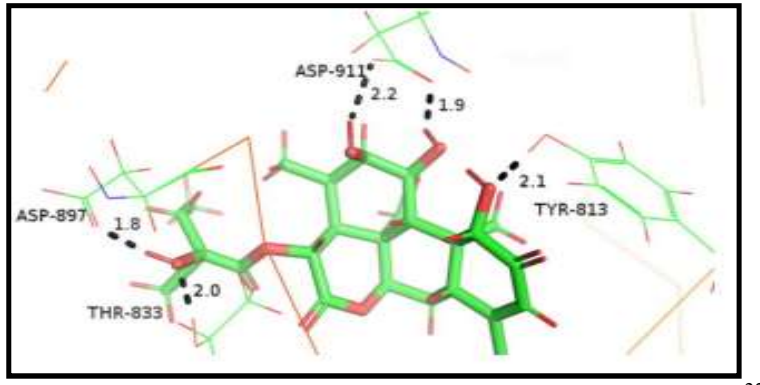

Fig.-11:Docking Image of Glaucarubinone against PI3K ${ }^{32}$

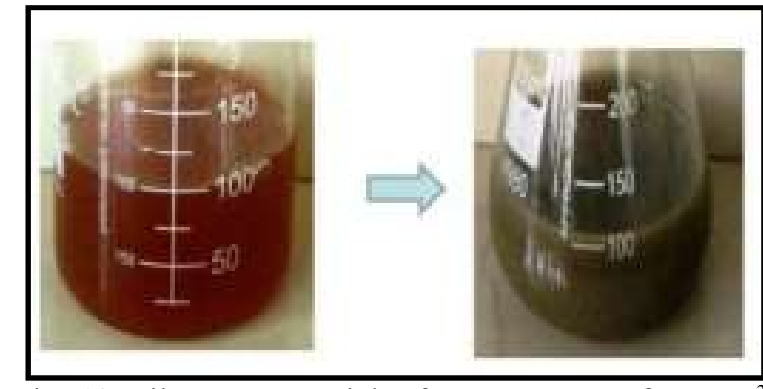

Fig.-12: Silver Nanoparticles from SBGA Leaf Extract ${ }^{33}$

Medium polar ethyl acetate and non-polar petroleum ether solvent extracts of the leaves were carried for antibacterial, antioxidant by different methods. ${ }^{35}$ Ethyl acetate extract exposed good antioxidant nature when compared to non-polar solvent extract. Using SBGA leaf extract, pure $\mathrm{ZnO}$ nanoparticles were prepared for the antioxidant and antimicrobial study. ${ }^{36}$ The research revealed that the best biological 
RASĀYAN J. Chem.

Vol. 13 | No. 3 |1580-1588| July - September | 2020

compatibility of the leaf extracted $\mathrm{ZnO}$ nanoparticles. SBGA DC effect on the growing plant induced additives and regulators through organogenesis which is shown in Fig.-13. ${ }^{37}$

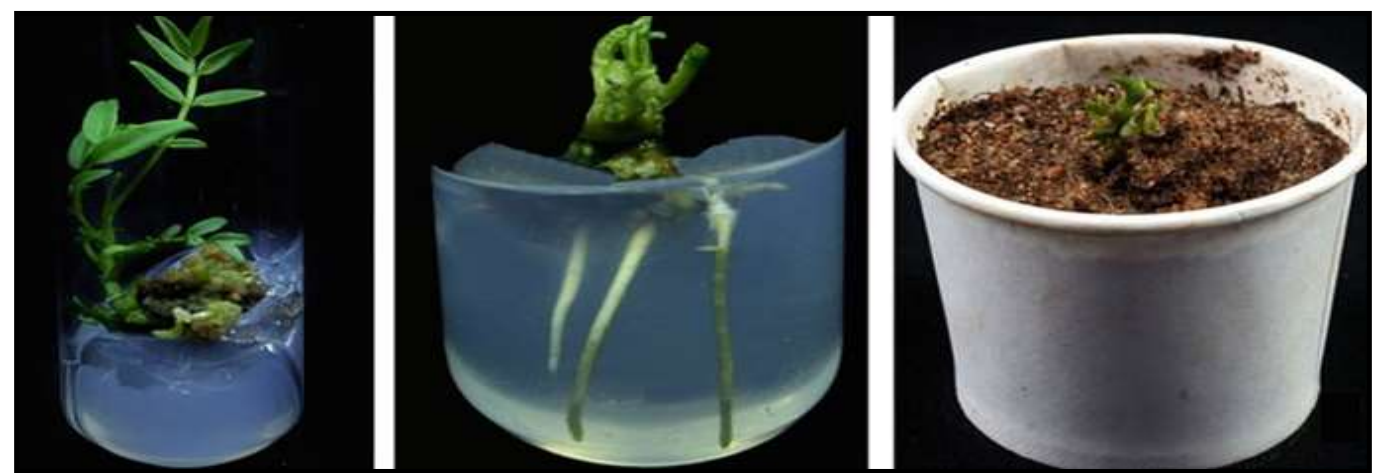

Fig.-13: Various Steps involved in SBGA Organogenesis ${ }^{37}$

Screening of the ethanolic and methanolic crude extracts for the antifungal activity on Fusarium oxysporum, Aspergillus parasiticus respectively. SBGA extract showed good inhibition against Aspergillus parasiticus. ${ }^{38}$ Leaves and bark of SBGA were collected for antibacterial activity against two pathogens such as S. sobrinus and S. mutan. ${ }^{39}$ Alcoholic leaf extracts of Anticancer SBGA were phytochemically analysed and using Thin Layer Chromatography compositions were compared. ${ }^{40}$ SBGA Bark, Flower and Leaves extracts were tested for their Anticancer Activity on Hct116 cancer Cells. ${ }^{41}$ The results revealed that the cell viability of chloroform extracts showed poor cell viability when compared to ethanol extracts- $35.8 \%$ at $50 \mu \mathrm{g} / \mathrm{ml}$ and methanol extract $-66.8 \%$ at $50 \mu \mathrm{g} / \mathrm{ml}$. The extract of SBGA showed anti-inflammatory activity and the resultant outcomes exposed the dropping of inflammatio.42 Antifungal activity of SBGA ethanolic extract against Aspergillus parasictus..$^{43}$ was tested and showed good results. The silver nanoparticles were prepared by green synthesis using SBGA leaf which showed good resistivity against common bacteria and antioxidant character ${ }^{44}$ The chemical structure and the functional groups of SBGA component glaucarubin have been reported and ten oxygen atoms of the molecule exposed lactone, six hydroxyl and ester. ${ }^{45}$ Using ethanol, aqueous and methanol SBGA bark extracts were carried for in-vitro antioxidant activity and exhibited promising activity. ${ }^{46}$ Similarly, more stable with antimicrobial active gold nanoparticles were prepared from SBGA leaf extract and characterized. ${ }^{47}$ SBGA callus (Fig.-14) and three places of the leaf (basal, middle, tip) random amplified polymorphic DNA was studied. The DNA sequence change was observed in SBGA due to media. ${ }^{48}$

More quantity of biodiesel (methyl ester) was prepared from SBGA seed oil using alkaline catalyzed transesterification. ${ }^{49}$ Both A. Muricata and SBGA leaf extracts were tested for E. Faecalis and the outcomes, not favored SBGA. ${ }^{50}$ The various parts extracts of SBGA insecticidal activity (Fig.-15) were tested against Plutella xylostella, Helicoverpa armigera respectively. The report confirmed the highest mortality of the bark methanolic extract. ${ }^{51}$

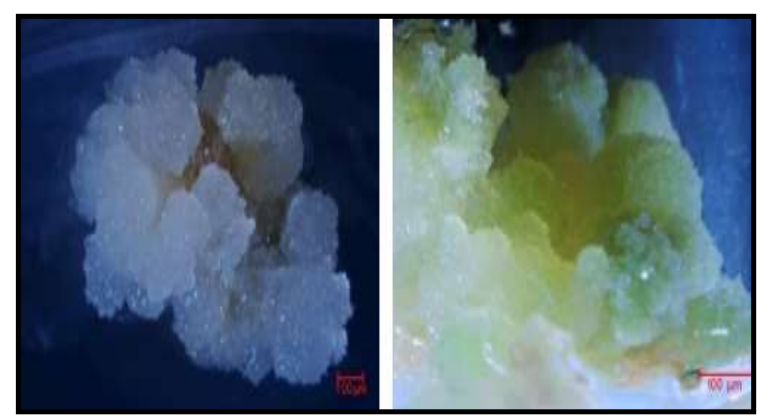

Fig.-14: Callus from 30 and 120 Days Culture ${ }^{48}$

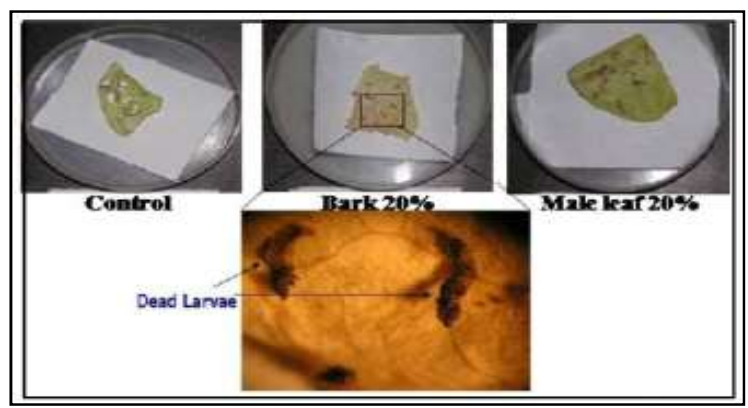

Fig.-15: Insecticidal Bioassay SBGA against Plutella xylostella $^{51}$

Due to the various biological efficacy of SBGA cropping development carried in nurseries. The raised bed method and polybag $(25 \times 18 \mathrm{~cm})$ are suitable for good cropping. ${ }^{52}$ In-vivo nephroprotective activity 
RASĀYAN J. Chem.

Vol. 13 | No. 3 |1580-1588| July - September | 2020

of SBGA in albino Rats was tested which is treated with gentamycin induction. The methanolic extract exposed a good effect in nephrotoxicity in test species. ${ }^{53}$ An effect of fungus pathogens $G$. mosseae plus, B. coagulans on SBGA nutrition was studied and they enhanced the nutrients, growth respectively. ${ }^{54}$ The low concentration acetone extract of SBGA leaf controlled the Allium cepa $L$ (miotic) cells. ${ }^{55}$ Similar way, green synthesis of copper nanoparticles was reported from Uncaria gambir ROXB ${ }^{56}$ Nowadays various plant extracts were used for medicinal uses including leaf extract of Coriandrum Sativum. ${ }^{57}$

\section{CONCLUSION}

From the various reports and reviews, this work observed and noticed the importance of the selected plant SBGA in the medical field. But, some of the extracts and their usefulness are not clearly explained still now. Most of the research papers reported the phytochemical analysis with biological activity of the SBGA plant. Only a few research reports have characterized the isolated extracts using different analytical techniques. The limited reports of SBGA are observed on therapeutic effectiveness and usefulness of synthesized nanoparticles by the pollution-free method. Extraction methods, solvent effect, chemical constituents, nanoparticle preparations and the applications in a wide range of anti-microbes are lacking. Hence this will be useful for future researchers.

\section{REFERENCES}

1. M. Pandey, S. Rastogi, S., and A.K.S. Rawat, Evidence-Based Complementary and Alternative Medicine, 1(2013), DOI:10.1155/2013/376327

2. S. Parasuraman, Current Pharmacogenomics and Personalized Medicine, 16, 63(2018), DOI: $10.2174 / 1875692116666180419153313$

3. J. Rout, A.L. Sajem and M. Nath, Indian.Journal of Traditional Knowledge, 11(3), 520(2012)

4. M. Ekor, Front Pharmacology, 177, 1(2014)

5. A.H. Hussin, Malaysian Journal of Pharmacy, 39(2001)

6. B. Petrovska, Pharmacognosy Reviews, 6, 1(2012), DOI:10.4103/0973-7847.95849

7. J. Antony, A.Thomas, D.Gnanasekaran and H.Elizabeth, International Journal of New Technology and Research, 2(10), 59(2016)

8. S.Joshi and S.Joshi, University of Agricultural sciences, Bangalore and Indian council of Agricultural Research, New Delhi, India, 86(2002)

9. I. Arivu, M. Muthulingam, and R. Palaniappan, Journal of Advanced Scientific and Technical Research, 1(7), 86(2017)

10. A. Jose, A.Chaitanya, E. Kannan, and S.V. Madhunapantula, Frontiers in Pharmacology, 9(2018), DOI: 10.3389/fphar.2018.00127

11. I.P. Sridevi, S.C. Ghagane, R.B. Nerli, S.S. Jalalpure, and M.B. Hiremath, Pharmacognacy Journal, 9, 906(2017), DOI:10.5530/pj.2017.6.142

12. K.Santhanalakshmi, D. Sangeetha, S.Sivamani, M.Tamilarasan, T.P Rajesh, and B.Anandraj. International Journal of Pharmaceutical Sciences and Research. 5(2), 432(2014)

13. B.M. Rajurkar, International Journal of Research and Review in Pharmacy and applied science, 1(4), 278(2011)

14. M.S. Patil and D.Gaikwad, Journal of Pharmaceutical Science and Research, 3, 1195(2011)

15. M.P. Padovan, V.J. Cortez, L.F. Navarrete, E.D. Navarrete, A.C. Deffner, L.G. Centeno, and B. Rapidel, Agroforestry Systems, 89(5), 857(2015), DOI:10.1007/s10457-015-9820-z

16. G. Vaidya, G. R. Naik, International Journal of Current Research Reviews, 10(5), 46(2018), DOI: 10.7324/ IJCR R. 2018.1058

17. R. L. Chavan and B. V. Tembhurne, Karnataka Journal of Agricultural Science, 28(2), 235(2015)

18. V.K.Sharanya, K. Gayathiri, M. Sangeetha and G.Shyam Prakash, G.S.Kumar, J. V. Vathini and R.S. Kavimani, International Journal of Pharma Research \& Review, 5(6), 32(2016)

19. V.F. Assendelft, D.T. Mintz, J.A.Schack, P. Ottolenghi, and H.Most, American Journal of Tropical Medicine and Hygiene, 5(3), 501(1956)

20. G. Kartha, D. J. Haas, H.M. Schaffer, and K.K. Kaistha, Nature, 202 (4930), 389(1964), DOI: $10.1038 / 202389 b 0$ 
RASĀYAN J. Chem.

Vol. 13 | No. 3 |1580-1588| July - September | 2020

21. R. Duffy, C. Wade, and Chang, R, Drug Discovery Today, 17, 942(2012), DOI: 10.1016/j.drudis. 2012.03.013

22. J. F. Rivero-Cruz, R. Lezutekong, T. Lobo-Echeverri, A. Ito, Q. Mi, H. B. Chai, D. D. Soejarto, G. A. Cordell, J. M. Pezzuto, S. M. Swanson, I. Morelli and A. D.Kinghorn, Phytotherapy Research, 19(2), 136(2005), DOI:10.1002/ptr.1642

23. S. Bhatnagar, J. Polonsky, T. Prange and C. Pascard, Tetrahedron Letters, 25(3), 299(1984), DOI: 10.1016/s0040-4039(00)99867-8

24. L. Simon, P. Narayanaswamy, and S. Joshi, S. The Journal of Horticultural Science and Biotechnology, 84(5), 510(2009), DOI:10.1080/14620316.2009.11512557

25. N.Sajeeda, K.Rr, S. Shivakumara, Y. Shivaraj, and C.S. Karigar, Asian Journal of Pharmaceutical and Clinical Research, 12(9), 56(2019)

26. Iasmine A.B.S. Alvesa, Henrique M. Mirandab, Luiz A.L. Soaresa and K.P. Randau, Revista Brasileira de Farmacognosia, 24, 481(2014)

27. A.Kumar, G. Tyagi, Sunayana Sharma, Vikas Kumar and Reena Pundir, Indian journal of Pharmacology, 1(12), 735(2014)

28. C.K. Prajapati, M.N. Reddy and M.H. Bhatt, International Journal of Botany Studies, 3(2), 52(2018)

29. F.C. Valdés, A, M. Martinez, J. S. Lizama, R. Vermeersch, M. Cos, P.L. Maes, Memorias Do Instituto Oswaldo Cruz, 103(6), 615(2008), DOI:10.1590/s0074-02762008000600 019

30. B. Vikas, B.S. Akhil, S.R. Suja, and K. Sujathan, Asian Pacific Journal of Cancer Prevention, 18(7), 1765(2017), DOI: 10.22034/APJCP.2017.18.7.1765

31. S.Dinesh, D.S.N. Sasikumar, B. Girija, V.Lakshmipriya, Panicker, P.V.Kumar, S.Preetha and S.S.Sarma, Journal of Applied Pharmaceutical Science, 7(09), 142(2017), DOI:10.7324/JAPS.2017.70 919

32. K. S. Ramya, S. Iqbal, K.Gunasekaran, A.Radha, Research Journal of Life Sciences, Bioinformatics, Pharmaceutical and Chemical Sciences, 218(2018)

33. C. P. Chandrappa, N. Chandrasekar, M. Govindappa, C. Shanbhag, U. K. Singh, J. Masarghal, International Journal of Current Pharmaceutical Research, 9(4), 19(2017)

34. Ramesh, L. Cathrine, S. Gurupriya P. Pratheema, International Journal for Research in Applied Science \& Engineering Technology, 6(III), 933(2018)

35. S. Kochath, S.A.Venugopal, M.C.Radhakrishnan, South Indian Journal of Biological Sciences, 2(1), 119(2016)

36. H. Kumar, N.K. Murali, M. Satish, A.B. Singh, S. Gowtham, H. G. Mahesh and H. M, Jagannath, Journal of Cluster Science, 31(2), 523(2020), DOI: 10.1007/ s10876-019-01669-7

37. A.R. Lavanya, M. Muthukumar, S. Muthukrishnan, V. Kumaresan, T. S. Kumar, M. V. Venkatesh, and M. V. Rao, Conservation and Crop Improvement, 71(2016), DOI:10.1007/978-981-10-1917-3_4

38. K. Mikawlrawng, S. Kaushik, A. K. Pushker, S. Kumar, M. K. Singh and G. S. Sharma, Journal of Medicinal Plants Studies, 2(3), 1(2014)

39. H.A. Salman, R.Senthilkumar and M. Vasundhara, Biosciences Biotechnology Research Asia, 15(2), 311(2018)

40. A. Kumar, V. Rawat, Amardeep and V. Kumar, International Journal of Current Microbiology and Applied Sciences, 5(6), 679 (2016)

41. S. Niketh, SL. Shivakumar, R.R. Kolgi, and C.S. Karigar, International Journal of Scientific \& Technology Research, 8(10), 69(2019)

42. N. T.Abdullah, N. H. Khair and R. Koneri, World Journal of Pharmaceutical Research, 7(15), 550 (2018), DOI: 0.20959/wjpr201815-12963

43. S. Kaushik, K. Mikawlrawng, N.G. Sonone, S. Subramaniam and A. K. Choudhary, International Journal of Current Research, 6 (03), 5677(2014)

44. B. Hemashekhar, C. P. Chandrappa, M. Govindappa, N. Chandrasekhar, N. Ganganagappa and Y.L. Ramachandra, Int. Journal of Engineering Research and Application, 7 (8), 17(2017)

45. E.A. Ham, H. M. Schafer, R.G. Denkewalter, and N.G. Brink, Journal of the American Chemical Society, 76(23), 6066(1954), DOI: 10.1021/JA01652A060 
RASĀYAN J. Chem.

Vol. 13 | No. 3 |1580-1588| July - September | 2020

46. S.D.E. Osagie-Eweka, African Journal of Plant Science, 12(1), 7(2018), DOI: 10.5897/AJPS2017. 1547

47. N. Thangamani and N. Bhuvaneshwari, N, Chemical Physics Letters, 732, 2614(2019), DOI: 10.1016/J.CPLETT.2019.07.015

48. J Kakuturu, PC Josekutty, S Potlakayala, M Reitzel, K Salim, S Charyulu, R Adeyiga, S Menon, SL Goldman, P Patel, MJ Chorney and S Rudrabhatla, African Journal of Biotechnology, 13(53), 4766 (2014)

49. S.R. Mishra, M.K. Mohanty, S.P. Das and A.K. Pattanaik, Research Journal of Chemical Sciences, 2(5), 66(2012)

50. J. Mathew, R. George, R. Theruvil, T.C. Padavil, L. Tomy and A. Kurian, The Journal of Contemporary Dental Practice, 17(8), 650(2016)

51. S.S. Bangar, M.S. Dudhare, A.G. Deshmukh and H.A. Wagh, Agriculture Update, 12, 436 (2017)

52. R. L. Chavan and V. Tembhurne, Karnataka Journal of Agriculture Science 28(2), 235 (2015)

53. N.T.Abdullah, R. Koneri and D. K. Jha, Journal Pharaceutical Sciences Review and Research, 51(1), 182(2018)

54. G.L. Sailo, and D.J. Bagyaraj, Biological Agriculture \& Horticulture, 20(4), 339(2003), DOI: $10.1080 / 01448765.2003 .9754977$

55. S.V. Ajith, Chandralekha and C.T, BinuThomas, World Wide Journal Of Multidicipinary Research And Development, 3(7), 35(2017)

56. N. Elisma, A. Labanni, Emriadi, Y. Rilda, M. Asrofi and S. Arief, Rasayan Journal of Chemistry, 12 (4), 1752(2019), DOI: 10.31788/RJC.2019.1245347

57. S.M. Sinaga, G. Haro, S. Sudarmi and Iksen, Rasayan Journal of Chemistry, 12(4),1992(2019), DOI: 10.31788/RJC.2019.1245451

[RJC-5793/2020] 